\title{
Influence of a combination of triptolide and ferulic acid on the activities of CYP450 enzymes and oxidative stress in HaCaT cells
}

\author{
JIANLIN ZHANG, YONGMEI GUAN, LIANGFEI HE, LING TAO, ZHENHZONG ZANG, \\ WEIFENG ZHU, LIHUA CHEN and CHEN JIN \\ Key Laboratory of Modern Preparation of Traditional Chinese Medicine, Ministry of Education, \\ Jiangxi University of Traditional Chinese Medicine, Nanchang, Jiangxi 330004, P.R. China
}

Received August 10, 2019; Accepted March 24, 2020

DOI: $10.3892 /$ etm.2020.9286

\begin{abstract}
Topical administration of triptolide (TP) is effective in the treatment of rheumatoid arthritis (RA), but it can also induce skin irritation. Previous studies have used data mining strategies to analyze the application of Tripterygium wilfordii in the treatment of RA and have shown that TP and ferulic acid (FA) can be used in combination due to their component compatibility. The aims of the present study were to investigate the mechanisms underlying the effects of TP treatment and to identify its effects on metabolism and oxidative damage in the skin. MTT assay results suggested that the $\mathrm{HaCaT}$ cell survival rate was significantly increased when the compatibility ratio of TP to FA was 1:100. Moreover, the combination of TP with FA (TP + FA) did not significantly affect the activities of the cytochrome P40 (CYP) enzymes CYP family 1 subfamily A member 2 (CYP1A2), CYP2E1 and CYP3A4, when used as a 'cocktail'. It was found that $\mathrm{TP}+\mathrm{FA}$ significantly decreased the production levels of reactive oxygen species (ROS), superoxide dismutase and malondialdehyde in $\mathrm{HaCaT}$ cells, while significantly increasing levels of glutathione and catalase. In addition, $\mathrm{TP}+\mathrm{FA}$ significantly increased nuclear factor erythroid 2-related factor 2 protein expression, compared with TP alone. Thus, the present results indicated that the underlying mechanism of TP + FA efficacy may be related to decreased ROS production level in $\mathrm{HaCaT}$ cells, increased production levels of key antioxidant factors and increased antioxidant activity of the epidermis, all of which were correlated with a protective effect against oxidative damage.
\end{abstract}

Correspondence to: Dr Yongmei Guan or Dr Lihua Chen, Key Laboratory of Modern Preparation of Traditional Chinese Medicine, Ministry of Education, Jiangxi University of Traditional Chinese Medicine, 1688 Meiling Road, Nanchang, Jiangxi 330004, P.R. China

E-mail: guanym2008@163.com

E-mail: chlly98@163.com

Key words: triptolide, ferulic acid, cytochrome $\mathrm{P} 450$ enzymes, oxidative damage, nuclear factor erythroid-2-related factor 2

\section{Introduction}

Triptolide (TP) is one of the main monomer constituents that can be derived from Tripterygium wilfordii (1). Previous clinical studies have shown that TP has significant anti-inflammatory and immunosuppressive activities, and it has been widely used in the treatment of rheumatoid arthritis (RA) in China (2-4). However, TP is also toxic in humans, and its multiorgan toxicity prevents further application in clinical practice (5). The development of external TP preparations has become more efficient, and percutaneously administered TP has been efficacious in the treatment of RA (6-8). However, our previous study revealed that transdermal administration of TP can produce specific toxicities in the skin (9).

Ferulic acid (FA) is a type of phenolic acid with medicinal values and is found in plant tissues (10). FA is a primary component of the traditional Chinese medicinal herbs Angelica sinensis and Ligusticum chuanxiong FA, and has been suggested to possess anti-inflammatory and antioxidative pharmacological activities, which contribute to its therapeutic effect on RA $(11,12)$. Previous studies have shown that TP and FA (TP + FA) can be combined due to their component compatibility (13-15). Additionally, our previous study performed pharmacodynamic and toxicological experiments in a type II collagen-induced arthritis rat model and showed that the combination of TP + FA exerts significant anti-inflammatory effects and reduces skin irritation (data not published). However, to the best of our knowledge, the underlying mechanisms of TP + FA treatment in decreasing skin irritation have not been previously investigated. Oxidative stress can cause many diseases, and it is closely related to cell dysfunction, membrane structure, protein production, DNA changes and other cellular functions (16-18). Moreover, oxidative stress can result in loss of skin cells and degradation of the extracellular matrix (16-18). Cytochrome P450 (CYP) enzymes are important for controlling the normal physiological function and homeostasis of the internal environment of the skin. Moreover, CYP enzymes maintain the integrity and barrier role of the epidermis via biotransformation of exogenous and endogenous substances $(19,20)$.

$\mathrm{HaCaT}$ cells are a cultured human keratinocyte cell line. The culture method for maintaining HaCaT cells is simple, and these cells can proliferate indefinitely (21). In addition, 
$\mathrm{HaCaT}$ cells exhibit similarities to primary keratinocyte cells in the activity of drug-metabolizing enzymes (22). In the present study $\mathrm{HaCaT}$ cells were cultured in vitro as a model of an active epidermis with the aim to investigate the underlying mechanisms of FA in reducing skin toxicity in relation to metabolism and oxidative damage to skin. The aim of the present study was to provide a theoretical basis for the potential clinical application and development of external TP preparations.

\section{Materials and methods}

Materials and reagents. HaCaT cells (cat. no. ZQ0044) were supplied by Shanghai Zhongqiao Biotechnology Co., Ltd. TP (purity $>98 \%$ ) and FA (purity $>98 \%$ ) were purchased from Chengdu Pufei De Biotech Co., Ltd. Chlorzoxazol, testosterone and fenacetin were provided by Chengdu Derrick Biotechnology Co., Ltd. Reactive oxygen species (ROS, cat. no. 20180815), glutathione (GSH, cat. no. 20180721), malondialdehyde (MDA, cat. no. 20180730), superoxide dismutase (SOD, cat. no. 20180721) and catalase (CAT, cat. no. 20180811) assay kits were obtained from Nanjing Jiancheng Bio-Engineering Institute Co., Ltd. A nuclear factor erythroid 2-related factor 2 (Nrf2) antibody was purchased from Abcam (cat. no. Ab92946) and a $\beta$-actin antibody (cat. no. AC026) from ABclonal Biotech Co., Ltd. DMEM was obtained from Beijing Solarbio Science \& Technology Co., Ltd and FBS was obtained from Shanghai Jikai Ecox Biotechnology Co., Ltd.

HaCaT cell culture. HaCaT cells were grown in DMEM (4.5 g/l glucose) containing antibiotics $(100 \mathrm{U} / \mathrm{ml}$ penicillin and $100 \mu \mathrm{g} / \mathrm{ml}$ streptomycin) and supplemented with $10 \%$ FBS at $37^{\circ} \mathrm{C}$ in a $5 \% \mathrm{CO}_{2}$ incubator. Medium was replaced every 2-3 days. The 7-20th generations of cells were used in subsequent experiments. Cell density was adjusted to $1 \times 10^{5}$ cells $/ \mathrm{ml}$. Cells were seeded into 96-well plates to carry out MTT assays and 6-well plates for all other experiments.

MTT assay. Cell cytotoxicity and the optimum ratio of TP to FA was determined using an MTT assay. $\mathrm{HaCaT}$ cells were seeded into 96 -well plates $\left(2 \times 10^{4}\right.$ cells/well $)$ in a complete growth medium [High glycemic DMEM (4.5 g/l D-glucose, L-glutamine) containing $10 \%$ fetal bovine serum, $1 \%$ double antibody (100 U/ml penicillin, $100 \mathrm{~g} / \mathrm{ml}$ streptomycin)] for $24 \mathrm{~h}$, and then treated for $6 \mathrm{~h}$ with TP at $37^{\circ} \mathrm{C}, \mathrm{FA}$, mixed solutions of the two drugs at different concentrations (The concentrations of the TP groups were 19.54, 39.07, 78.13, $156.25,312.5,625$ and $1,250 \mathrm{ng} / \mathrm{ml}$, TP and FA equal to $1: 12.5$, $1: 25,1: 50,1: 100,1: 120$ in the TP + FA groups, respectively) or a control group with an equivalent volume of DMEM to that of the experimental drugs. Cells were washed twice with Hank's Balanced Salt Solution (HBSS) and incubated with $5 \mathrm{mg} / \mathrm{ml}$ MTT solution for $4 \mathrm{~h}$ at $37^{\circ} \mathrm{C}$. The resulting formazan crystals were dissolved in $150 \mu \mathrm{l}$ DMSO, and optical density (OD) was measured at $490 \mathrm{~nm}$ using a microplate reader (MK3; Thermo Fisher Scientific, Inc.). Cell survival rate (\%) was calculated using the following formula: [OD 490 (treatment)-OD 490 (blank)/OD 490 (control)-OD 490 (blank)] x100. OD 490 (treatment) was the mean OD value of cells treated with the target drugs, OD 490 (control) was the mean OD value of untreated cells and OD 490 (blank) was the mean OD value of cells treated with HBSS. The combination ratio of TP to FA was determined when the cell survival rate was at its highest.

Liquid chromatography-mass spectrometry (LC-MS) method validation. The chromatographic conditions were as follows. Solvent A was $0.1 \%$ formic acid $(\mathrm{V} / \mathrm{V})$ in water and solvent B a gradient elution with acetonitrile. The elution conditions of testosterone and fenacetin were as follows: $0-1 \mathrm{~min}, 70-45 \% \mathrm{~A}$; 1-2.8 $\min , 45 \%$ A; $2.8-3 \min , 45-70 \%$ A; 3-5 min, $70 \%$ A. The elution conditions of chlorzoxazol and carbamazepine were as follows: 0-1.5 $\mathrm{min}, 80-25 \% \mathrm{~A}$; $1.5-3 \mathrm{~min}, 25 \% \mathrm{~A} ; 3-3.1 \mathrm{~min}$, $25-80 \% \mathrm{~A} ; 3.1-5.0 \mathrm{~min}, 80 \% \mathrm{~A}$. The flow rate was $0.3 \mathrm{ml} \cdot \mathrm{min}^{-1}$ and the column temperature was $30^{\circ} \mathrm{C}$.

LC-MS conditions. A liquid chromatography-triple quadruple bar mass spectrometer (AB SCIEX, MODEL no. QTRAAP 5500) was used. Testosterone and fenacetin were detected in positive ion mode, and chlorzoxazol, in negative ion mode. An electrospray ion source was used and the ion source temperature (TEM) was $500^{\circ} \mathrm{C}$, ionized voltage was $5,500 \mathrm{~V}$, curtain gas was at $35 \mathrm{psi}$, impact gas was at 7 psi, spray gas was at $50 \mathrm{psi}$ at the auxiliary heater at $50 \mathrm{psi}$. The details of the multiple reaction monitoring transitions assessed were as follows: The quantitative ion pairs of testosterone were 289.1/109, DP (V) 103, CE (eV) 79 (positive); the quantitative ion pairs of fenacetin were 180.2/109.8, DP (V) 97, CE (eV) 26 (positive); the quantitative ion pairs of Internal standard carbamazepine were 236.8/194, DP (V) 120, CE (eV) 27 (positive); the quantitative ion pairs of chlorzoxazol were 167.9/131.9, $\mathrm{DP}(\mathrm{V})-60, \mathrm{CE}(\mathrm{eV})-26$ (negative); and the quantitative ion pairs of internal standard carbamazepine were 234.1/188.8, DP (V) -158, CE (eV) -23 (negative).

Specificity. Specificity of the method for measuring concentrations of the three probe drugs was achieved by selecting a precursor ion and then detecting and quantifying product ions. Specificity was evaluated by comparing the chromatogram of blank HBSS from HaCaT cells with that of blank plasma spiked with analytes (23), as previously described, as well as that of HBSS samples obtained from cells after administration of mixed probe drugs at a testosterone: Fenacetin:Chlorzoxazol dose of 120:6:6 ng/ml after treatment for $6 \mathrm{~h}$ at $37^{\circ} \mathrm{C}$.

Linearity. Linearity of the developed analytical method was investigated by analyzing the matrix-matched construction via an internal standard approach (24), using mixed probe drugs at a series of concentrations. Testosterone was used at the following concentrations 480,240,120,60,30, 15, 7.5 and $3.75 \mathrm{ng} / \mathrm{ml}$ at $25^{\circ} \mathrm{C}$. Fenacetin and chlorzoxazol were used at concentrations of $24,12,6,3,1.5,0.75,0.38$ and $0.19 \mathrm{ng} / \mathrm{ml}$ at room temperature. Carbamazepine (National Institutes for Food and Drug Control; cat. no. 100142-201706) was used as an internal standard and at concentration of $0.01 \mathrm{ng} / \mathrm{ml}$. Taking the ratio of the target component to the peak area of carbamazepine as the longitudinal coordinate and the concentration as the transverse coordinate, linear regression was performed via LC-MS analysis (SCIEX TRIPLE QUAD 5500; SCIEX; Analyst 1.6.2 software control and data processing system) 
and the standard curve was drawn with the reciprocal of the concentration as the weighted coefficient (25). The quantitative limit was set to a signal-to-noise ratio of $\geq 10$.

Accuracy and precision. In total, six replicate analyses of the quality control (QC) samples (chlorzoxazol, testosterone and fenacetin) were prepared at three different concentrations (the concentrations of testosterone were 480, 120 and $30 \mathrm{ng} / \mathrm{ml}$, and the concentrations of fenacetin and chlorzoxazol were $24.0,6.0$ and $1.5 \mathrm{ng} / \mathrm{ml}$, respectively) on the same day to ensure inter-day accuracy and precision. The ratio of the actual measured concentration to the marked concentration was used to determine the recovery rate of the analytical method. The present study estimated intra-day precision by analyzing six replicate QC samples on three consecutive days. The relative standard deviation (RSD) was used to assess precision, and accuracy was defined as the percent ratios of the calculated concentrations to the nominal concentrations (26).

Stability. QC samples $(\mathrm{n}=6)$ at three concentrations (low, medium and high) were used to assess the freeze-thaw cycle stabilities of the mixed probe drugs chlorzoxazol, testosterone and fenacetin. All QC samples were stored at $-80^{\circ} \mathrm{C}$ and subjected to three freeze-thaw (at room temperature) cycles, each cycle lasted for $24 \mathrm{~h}$, and the concentrations were determined using LC-MS.

Investigation of probe drug reaction concentration and duration of treatment. The mixed probe drugs were administered to HaCaT cells at testosterone: Fenacetin:Chlorzoxazol doses of 240:12:12, 120:6:6, 60:3:3, 30:1.5:1.5, 15:0.75:0.75 and 7.5:0.375:0.375 ng/ml. Cell survival rate (\%) was calculated using the methodology described previously.

Mixed probe drugs were added to $\mathrm{HaCaT}$ cells at a density of $2 \times 10^{5}$ in 6 -well plates at $37^{\circ} \mathrm{C}$. Then, $150 \mu 1$ samples were collected from every group at $0,0.5,1,2,4$ and $6 \mathrm{~h}$, and the substrate concentrations of each probe was determined using the methodology described in the aforementioned description of LCMS validation.

Determination of CYP1A2, CYP2E1 and CYP3A4 enzymatic activities. In total, $150 \mu \mathrm{l}$ mixed probe drug samples were collected from each group (TP high dose, $156.25 \mathrm{ng} / \mathrm{ml}$, TP medium dose, $78.13 \mathrm{ng} / \mathrm{ml}$ and TP low dose, $39.07 \mathrm{ng} / \mathrm{ml}$. TP + FA low dose, TP $39.07 \mathrm{ng} / \mathrm{ml}+\mathrm{FA} 3.907 \mu \mathrm{g} / \mathrm{ml}, \mathrm{TP}+\mathrm{FA}$ medium dose, TP $78.13 \mathrm{ng} / \mathrm{ml}+\mathrm{FA} 7.813 \mu \mathrm{g} / \mathrm{ml}$, and TP + FA high dose, TP $156.25 \mathrm{ng} / \mathrm{ml}+\mathrm{FA} 15.625 \mu \mathrm{g} / \mathrm{ml}$ ) of HaCaT cells after $2 \mathrm{~h}$ of treatment at $37^{\circ} \mathrm{C}$, and were centrifuged at $26,400 \mathrm{~g}$ for $10 \mathrm{~min}$ at $4^{\circ} \mathrm{C}$. Then, the upper layers of the samples were analyzed via LC-MS (AB SCIEX, TRIPLE QUDA 5500). Testosterone and fenacetin were detected in positive ion mode and chlorzoxazol in negative ion mode. The conditions were electrospray ion source, ion source temperature was $500^{\circ} \mathrm{C}$. Ionization voltage was $5,500 \mathrm{~V}$, curtain gas was at 35 psi, bump gas was at 7 psi, spray mist was at $50 \mathrm{psi}$ and the auxiliary heater was at $50 \mathrm{psi}$ in scan mode for multi-reaction monitoring. The specific methods were as described previously in this manuscript. The activities of cytochrome P450 (CYP) enzymes CYP family 1 subfamily A member 2 (CYP1A2), CYP2E1 and CYP3A4 were assessed using different concentrations of fenacetin $(6.0 \mathrm{ng} / \mathrm{ml})$, chlorzoxazol $(6.0 \mathrm{ng} / \mathrm{ml})$ and testosterone $(120.0 \mathrm{ng} / \mathrm{ml})$, respectively (27).

Measurement of intracellular ROS, GSH, CAT, SOD and MDA. $\mathrm{HaCaT}$ cells were seeded into 6 -well plates $\left(2 \times 10^{5}\right.$ cells/well $)$ in a complete growth medium for $48 \mathrm{~h}$. Cells were treated for $6 \mathrm{~h}$ with TP, FA and TP + FA at different concentrations (Table V) in DMEM at $37^{\circ} \mathrm{C}$. Generation of intracellular ROS was

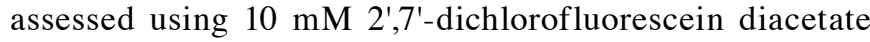
(DCFH-DA), a fluorescent probe, which is converted to the highly fluorescent derivative dichlorofluorescin via oxidation by ROS and peroxides (28). At the end of the drug action (after $6 \mathrm{~h}$ ), the residual liquid was discarded. Cells were incubated in the dark for $1 \mathrm{~h}$ at $37^{\circ} \mathrm{C}$ with $1 \mathrm{ml}$ DCFH-DA working solution (DCFH-DA:HBSS, 1:500) and then resuspended in HBSS ( $4.5 \mathrm{~g} / 1$ glucose). Fluorescence was analyzed using a multifunctional enzyme labeling instrument (Thermo Fisher Scientific, Inc.) with excitation at $488 \mathrm{~nm}$ and emission at $530 \mathrm{~nm}$. GSH, CAT, SOD and MDA activities in HaCaT cells were measured using commercially available kits following the manufacturer's instructions. Cells were collected by centrifugation $(1,530 \mathrm{x} g$ at $4^{\circ} \mathrm{C}$ for $10 \mathrm{~min}$ ) and suspended in HBSS ( $4.5 \mathrm{~g} / \mathrm{l}$ glucose). Cells were then broken by ultrasonication $(300 \mathrm{~W} ; 5 \mathrm{sec} /$ time; five times). The absorbance values were measured using an enzyme labeling instrument (MK3; Thermo Fisher Scientific, Inc.) to indicate the level of production of GSH, CAT, SOD and MDA.

Western blotting. $\mathrm{HaCaT}$ cells were seeded into 6-well plates $\left(2 \times 10^{5}\right.$ cells/well) in a complete growth medium for $48 \mathrm{~h}$ and were assigned into seven groups: 3 TP group $(39.07,78.13$ and $156.25 \mathrm{ng} / \mathrm{ml})$ and $3 \mathrm{TP}(39.07,78.13$ and $156.25 \mathrm{ng} / \mathrm{ml})$ : FA (1:100) group and a negative control group (Blank solvent is DMEM). Cells were then harvested by scraping, collected in HBSS and centrifuged at $1,530 \mathrm{xg}$ for $5 \mathrm{~min}$ at $4^{\circ} \mathrm{C}$ before they were mixed with lysis buffer (RIPA; Beijing Solarbio Science \& Technology Co. Ltd.) and placed on ice for $20 \mathrm{~min}$. Following lysis the suspension was centrifuged at $12,000 \mathrm{x} \mathrm{g}$ at $4^{\circ} \mathrm{C}$ for $15 \mathrm{~min}$. Protein was collected and the concentrations determined using a bicinchoninic acid protein assay kit (cat. no. 23225; Thermo Fisher Scientific, Inc.) according to the manufacturer's instructions. A total of $20 \mu \mathrm{g}$ of each protein was loaded for SDS-PAGE (12\%) before transfer onto PVDF membranes. Membranes were blocked with $10 \%$ goat serum for $2 \mathrm{~h}$ at $4^{\circ} \mathrm{C}$ before incubation with the primary antibodies (diluted in 5\% skimmed milk) at $4^{\circ} \mathrm{C}$ for $12 \mathrm{~h}$. Nrf2 $(1: 1,000)$ and $\beta$-actin $(1: 100,000)$ were used as primary antibodies and anti-mouse immunoglobulin $\mathrm{G}(1: 50,000)$ as the secondary antibody at $37^{\circ} \mathrm{C}$ for $1 \mathrm{~h}$. The blots were developed with ECL reagent (EMD Millipore; cat. no. WBKLS0010). The density of each protein band was analyzed and calculated using ImageJ version 1.44 (National Institutes of Health). Protein expression level was expressed as the ratio of $\mathrm{Nrf} 2$ to $\beta$-actin, and semi-quantitative analysis was performed.

Statistical analysis. Data are presented as the mean \pm SD from 3 parallel experiments per group. Analyses were performed using SPSS software version 21.0 (SPSS, Inc.). Differences between the treatment groups and the control group were assessed by one-ANOVA followed by 
Table I. Average optical densities of HaCaT cells among the experimental groups.

\begin{tabular}{lcccccc}
\hline & \multicolumn{7}{c}{ Combination ratio } \\
\cline { 2 - 7 } TP concentration, ng/ml & TP & $1: 12.5$ & $1: 25$ & $1: 50$ & $1: 100$ & $1: 120$ \\
\hline Control & $0.417 \pm 0.059$ & $0.460 \pm 0.069$ & $0.467 \pm 0.056$ & $0.398 \pm 0.033$ & $0.382 \pm 0.024$ & $0.432 \pm 0.041$ \\
1250 & $0.281 \pm 0.039$ & $0.356 \pm 0.038$ & $0.347 \pm 0.021$ & $0.303 \pm 0.029$ & $0.316 \pm 0.022$ & $0.337 \pm 0.042$ \\
625 & $0.282 \pm 0.038$ & $0.367 \pm 0.042$ & $0.351 \pm 0.034$ & $0.318 \pm 0.033$ & $0.327 \pm 0.016$ & $0.349 \pm 0.036$ \\
312.5 & $0.288 \pm 0.029$ & $0.375 \pm 0.050$ & $0.366 \pm 0.034$ & $0.333 \pm 0.026$ & $0.332 \pm 0.018$ & $0.355 \pm 0.036$ \\
156.25 & $0.286 \pm 0.034$ & $0.382 \pm 0.066$ & $0.381 \pm 0.015$ & $0.342 \pm 0.027$ & $0.354 \pm 0.039$ & $0.360 \pm 0.023$ \\
78.13 & $0.303 \pm 0.035$ & $0.384 \pm 0.012$ & $0.382 \pm 0.033$ & $0.342 \pm 0.016$ & $0.361 \pm 0.026$ & $0.364 \pm 0.024$ \\
39.07 & $0.325 \pm 0.027$ & $0.431 \pm 0.055$ & $0.445 \pm 0.035$ & $0.367 \pm 0.024$ & $0.363 \pm 0.022$ & $0.406 \pm 0.020$ \\
19.54 & $0.385 \pm 0.040$ & $0.429 \pm 0.014$ & $0.480 \pm 0.016$ & $0.412 \pm 0.012$ & $0.416 \pm 0.009$ & $0.432 \pm 0.022$ \\
\hline
\end{tabular}

Data are presented as the mean $\pm \mathrm{SD}$. $\mathrm{n}=6$. Control, without TP and FA; TP, TP alone; 1:12.5, TP:FA=1:12.5; 1:25, TP:FA=1:25; 1:50, TP:FA=1:50; 1:100, TP:FA=1:100; 1:120, TP:FA=1:120. TP, triptolide; FA, ferulic acid.

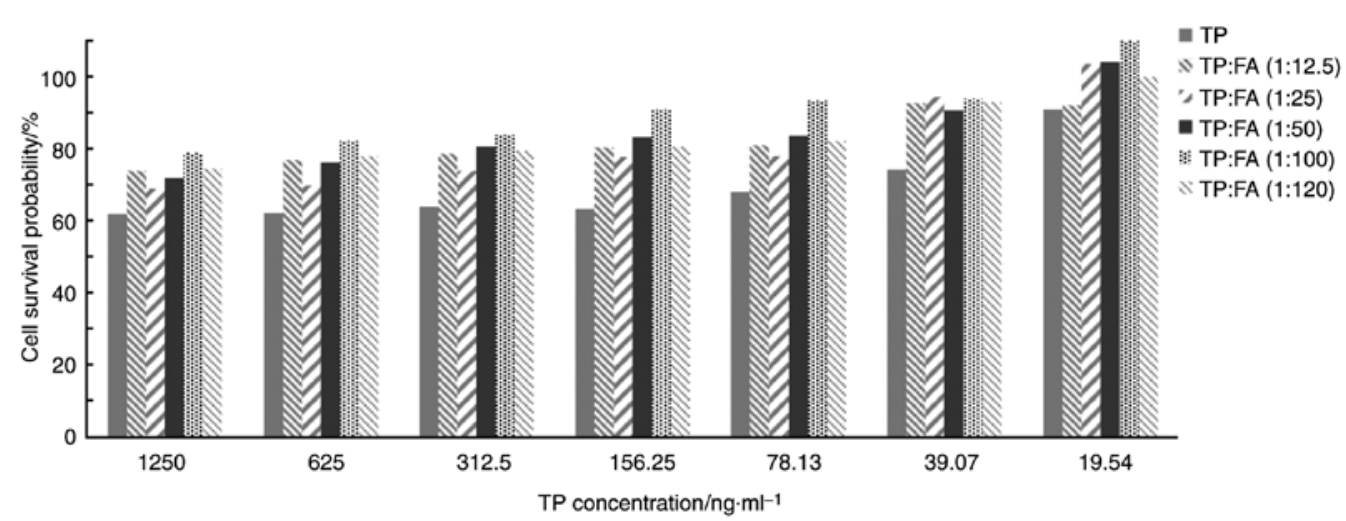

Figure 1. Effects of TP + FA on the survival probability of $\mathrm{HaCaT}$ cells. Survival probability was determined as the number of living cells in the treatment groups compared with the control group. TP, triptolide; FA, ferulic acid.

a least-significant-difference test. $\mathrm{P}<0.05$ was considered to indicate a statistically significant difference.

\section{Results}

Determination of the compatibility ratio of $T P$ to $F A$. It was found that TP inhibited the viability of $\mathrm{HaCaT}$ cells in a dose related manner, with higher doses reducing cell viability (Table I; Fig. 1). The cell survival rate was $<90 \%$ when the concentration of TP $>19.54 \mathrm{ng} / \mathrm{ml}$. When the concentration of FA was $<150 \mu \mathrm{g} / \mathrm{ml}$, FA had no effect on the survival of $\mathrm{HaCaT}$ cells. However, the inhibitory effect on $\mathrm{HaCaT}$ cell survival was significantly decreased when TP + FA was administered. Moreover, the survival rate of $\mathrm{HaCaT}$ cells was increased at TP + FA combination ratios of 1:12.5, 1:25, 1:50, 1:100 and 1:120, compared with the TP alone group. The effect on cell survival of the TP + FA combination ratio 1:100 was $>7$ times higher compared with TP alone. Therefore, the present results indicated that the compatibility ratio of TP + FA was 1:100.

Influence of TP $+F A$ on activities of CYP450 enzymes and method validation

Specificity. It was found that none of the reagents or disposables used for method setup interfered with detection or quantification of probe drugs. Furthermore, false-positive responses and co-eluting components were not detected in analyzed biomatrices, and no carryover was observed (Fig. 2).

Linearity. Calibration curves showed excellent linearity ( $r>0.999)$ at the following concentration ranges: $3.75-480 \mathrm{ng} / \mathrm{ml}$ for testosterone, $0.19-24 \mathrm{ng} / \mathrm{ml}$ for fenacetin and $0.38-24 \mathrm{ng} / \mathrm{ml}$ for chlorzoxazol (Table II).

Accuracy and precision. The present study validated the accuracy and precision, including both intra-day and inter-day precision, of the three probe drugs in $\mathrm{HaCaT}$ cells. It was demonstrated that the results were all acceptable (RSD, $<15 \%$; Tables III and IV).

Stability. The present study also evaluated the stability of the three probe drugs under various conditions by analyzing six replicates of QC samples at low, middle and high concentrations. The RSDs high, medium and low QC samples of testosterone were $3.04,1.82$ and $1.78 \%$, respectively. The RSDs of high, medium and low concentration QC samples of fenacetin were $3.43,1.63$ and $3.57 \%$, respectively. The RSDs of high, medium and low concentration quality control samples 

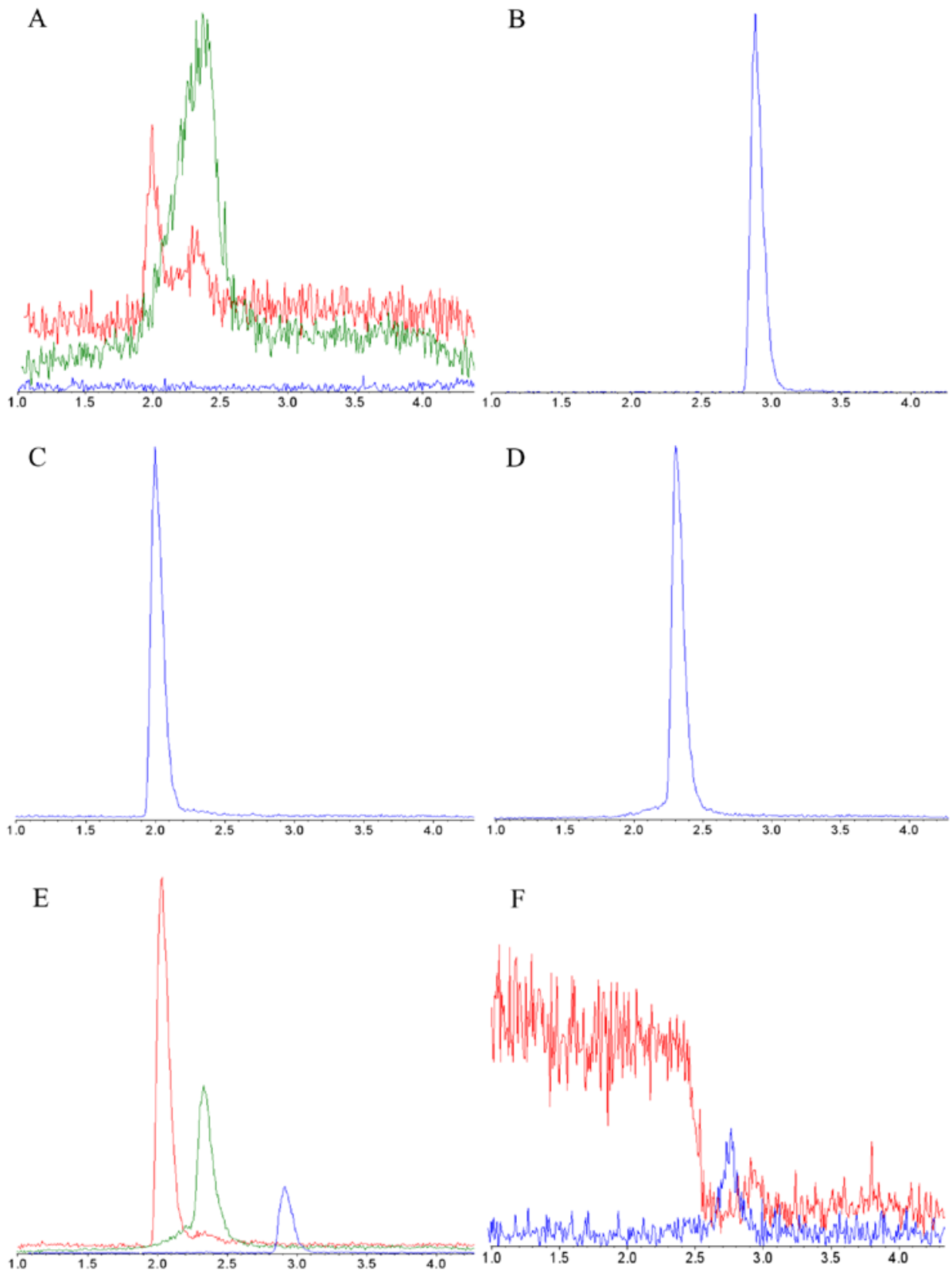

Figure 2. (A) Blank sample; (B) Testosterone reference; (C) Fenacetin reference; (D) Carbamazepine reference; (E) sample; (F) blank sample (negative mode); (G) Chlorzoxazol reference; (H) Carbamazepine reference (negative ion mode); I sample.

of chlorzoxazol were 5.26, 1.01 and $1.33 \%$, respectively. It was demonstrated that the RSDs of all QC samples were within $6 \%$, which was $<15 \%$.

Influence of TP + FA on the activities of CYP450 enzymes Investigation of probe drug incubation, concentration and duration of treatment. MTT assay results indicated that no mixed probe substrate group had any significant effect on the growth of the $\mathrm{HaCaT}$ cells. Moreover, it was found that the probability of cell survival was greatest when the ratio of concentrations of testosterone: Fenacetin: Chlorzoxazol was 120:6:6 ng/ml (Fig. 3).

Mixed probe drug solutions containing testosterone, fenacetin and Chlorzoxazol were administered at a dose of 120:6:6 ng/ml to HaCaT cells in each group, and the concentrations of the samples were determined. It was identified that in the 1st $\mathrm{h}$ of administration, the concentration of chlorzoxazol (Fig. 4C) in the incubation system decreased, and after this time point the concentration remained relatively unchanged. However, the concentration of testosterone (Fig. 4A) and fenacetin (Fig. 4B) appeared decreased within $2 \mathrm{~h}$ of administration, after which the reductions were slower, thus the incubation time was determined to be $2 \mathrm{~h}$.

Determination of CYP450 enzymatic activities. The present results suggested that the metabolic activity of fenacetin was reduced in the TP group compared with the control group. Furthermore, in the high dose 1:100 TP + FA combination group a decrease in fenacetin concentration was observed, compared with the TP group (Fig. 5). However, this difference was not significant, thus indicating that the compatibility 
Table II. Linear regression equation, linear range, LOD and LOQ for the three probe drugs.

\begin{tabular}{lccc}
\hline Probe drugs & Linear regression equation & Correlation coefficient & LOD, ng/ml \\
\hline Testosterone & $Y=0.00179 X-0.00132$ & 0.9999 & 3.75 \\
Fenacetin & $Y=0.207 X+0.0268$ & 0.9993 & 0.035 \\
Chlorzoxazol & $Y=0.1289 X+0.0357$ & 0.9994 & 0.018 \\
\hline
\end{tabular}

LOD, limit of detections; LOQ, limit of quantity; $Y$, longitudinal coordinate; $X$, transverse coordinate.

Table III. Results of precision determination of the three probe drugs.

\begin{tabular}{|c|c|c|c|c|c|}
\hline \multirow[b]{2}{*}{ Analytes } & \multirow[b]{2}{*}{$\mathrm{QC}, \mathrm{ng} / \mathrm{ml}$} & \multicolumn{2}{|c|}{ Intra-day $(n=6)$} & \multicolumn{2}{|c|}{ Inter-day $(n=6)$} \\
\hline & & Estimated value, $\mathrm{ng} / \mathrm{ml}$ & $\mathrm{RSD}, \%$ & Estimated value, $\mathrm{ng} / \mathrm{ml}$ & $\mathrm{RSD}, \%$ \\
\hline \multirow[t]{3}{*}{ Testosterone } & 480 & $479.5 \pm 8.38$ & 1.52 & $468.5 \pm 31.74$ & 6.77 \\
\hline & 120 & $117.8 \pm 1.60$ & 1.36 & $119.54 \pm 2.04$ & 1.71 \\
\hline & 30 & $29.9 \pm 0.80$ & 1.75 & $30.06 \pm 1.47$ & 4.88 \\
\hline \multirow[t]{3}{*}{ Fenacetin } & 24 & $24.12 \pm 0.36$ & 1.50 & $23.43 \pm 0.64$ & 2.74 \\
\hline & 6 & $6.08 \pm 0.16$ & 2.56 & $5.96 \pm 0.14$ & 2.27 \\
\hline & 1.5 & $1.58 \pm 0.06$ & 3.78 & $1.51 \pm 0.07$ & 4.69 \\
\hline \multirow[t]{3}{*}{ Chlorzoxazol } & 24 & $25.88 \pm 0.58$ & 2.25 & $25.95 \pm 0.63$ & 2.44 \\
\hline & 6 & $6.81 \pm 0.17$ & 2.46 & $6.06 \pm 0.40$ & 6.54 \\
\hline & 1.5 & $1.55 \pm 0.02$ & 1.29 & $1.54 \pm 0.05$ & 3.34 \\
\hline
\end{tabular}

Data are presented as the mean $\pm \mathrm{SD}$. QC, quality control; RSD, relative standard deviation.

Table IV. Results of accuracy determination of the probe drugs.

\begin{tabular}{lccc}
\hline Analytes & QC, ng/ml & Percent recovery, \% & RSD, \% \\
\hline Testosterone & 480 & $102.79 \pm 3.75$ & 3.65 \\
& 120 & $101.50 \pm 2.85$ & 2.81 \\
Fenacetin & 30 & $105.33 \pm 1.35$ & 1.29 \\
& 24 & $100.75 \pm 2.75$ & 2.73 \\
Chlorzoxazol & 6 & $99.87 \pm 1.75$ & 1.75 \\
& 1.5 & $90.27 \pm 3.22$ & 3.56 \\
& 24 & $107.82 \pm 2.43$ & 2.25 \\
& 6 & $113.54 \pm 2.79$ & 2.46 \\
& 1.5 & $103.47 \pm 1.34$ & 1.29
\end{tabular}

Data are presented as the mean $\pm \mathrm{SD}$. QC, quality control; RSD, relative standard deviation.

of TP + FA had no effect on CYP1A2 activity in HaCaT cells. Moreover, the present results suggested that combined TP + FA treatment did not significantly change the activity of CYP2E1 or CYP3A4 (Fig. 5).

Protective effect of $T P+F A$ against oxidative damage in HaCaT cells

Detection of antioxidant factors in HaCaT cells. It was demonstrated that the production levels of ROS, SOD and
Table V. Results of stability determination of the three probe drugs

\begin{tabular}{lccc}
\hline Analytes & QC, ng/ml & Estimated, ng/ml & RSD,\% \\
\hline Testosterone & 480 & $482.80 \pm 14.67$ & 3.04 \\
& 120 & $115.80 \pm 2.11$ & 1.82 \\
Fenacetin & 30 & $27.74 \pm 0.49$ & 1.78 \\
& 24 & $22.36 \pm 0.77$ & 3.43 \\
Chlorzoxazol & 6 & $6.27 \pm 0.10$ & 1.63 \\
& 1.5 & $1.44 \pm 0.05$ & 3.57 \\
& 24 & $25.36 \pm 1.33$ & 5.26 \\
& 6 & $6.52 \pm 0.07$ & 1.01 \\
& 1.5 & $1.48 \pm 0.02$ & 1.33 \\
\hline
\end{tabular}

Data are presented as the mean $\pm \mathrm{SD}$. QC, quality control; RSD, relative standard deviation.

MDA were significantly higher, and those of GSH and CAT significantly lower, in the TP group compared with the control group ( $\mathrm{P}<0.01$; Table VI; Fig. 6). Furthermore, it was found that FA reversed the regulatory changes in oxidation factors induced by TP. The production levels of ROS, SOD and MDA in $\mathrm{HaCaT}$ cells were significantly decreased, and those of GSH and CAT increased significantly, in the TP + FA group compared with TP-alone group. 


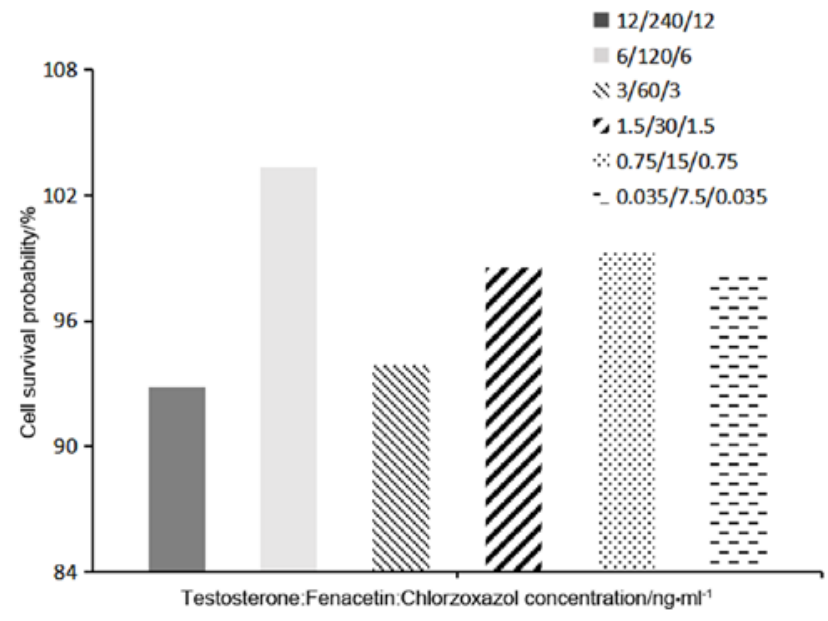

Figure 3. Effects of testosterone + fenacetin + chlorzoxazol on the survival probability of HaCaT cells.
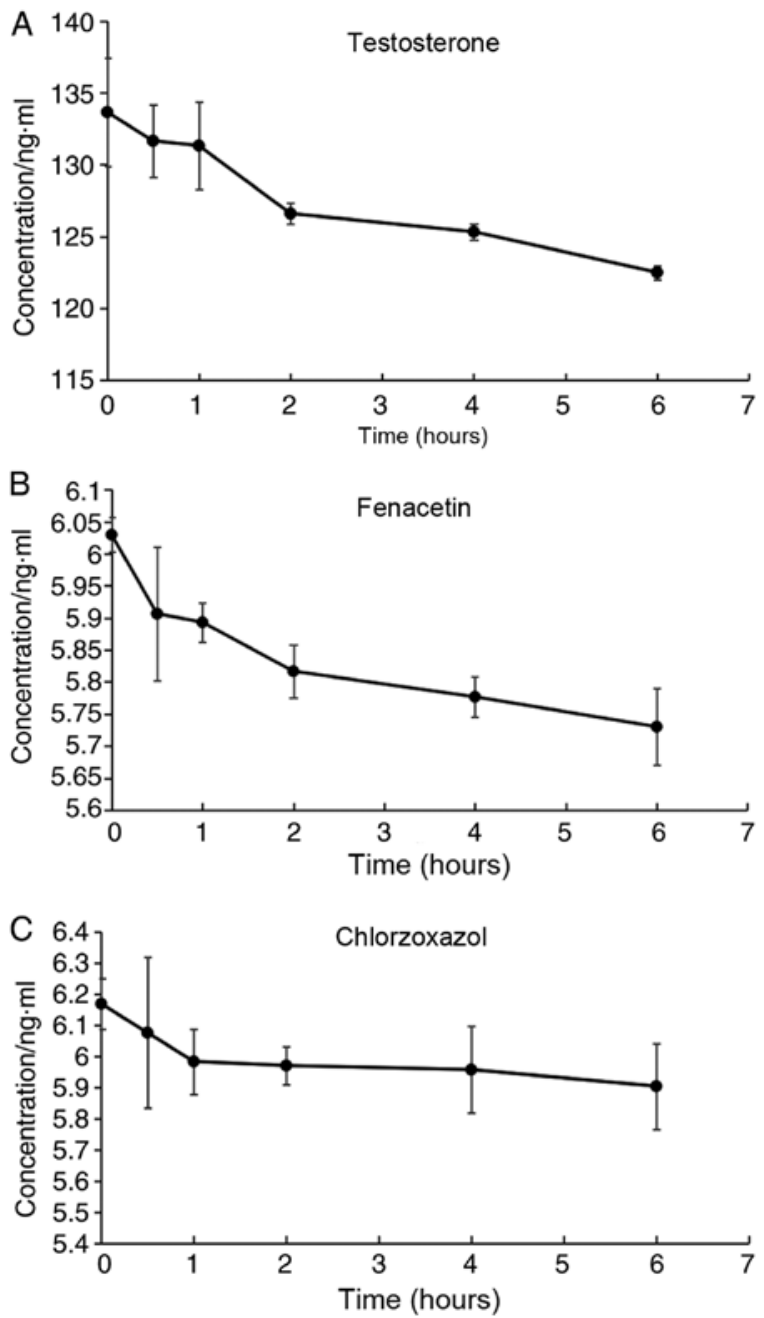

Figure 4. Concentration curve of mixed probe substrate in HaCaT cell incubation system. (A) Testosterone concentration. (B) Fenacetin concentration. (C) Chlorzoxazol concentration.

Expression of $\mathrm{Nrf2}$. The present results indicated that, compared with the control group, there was no significant difference in the protein expression of Nrf2 in the high- or low-dose TP group. However, it was found that cells treated with TP + FA showed upregulated Nrf2 protein expression, which was significant in the high-dose group $(\mathrm{P}<0.05$; Fig. 7$)$.

\section{Discussion}

Skin is the first physiological barrier of the human body and is also the largest organ (29). It not only protects the body from adverse external factors, but also prevents loss of moisture and nutrients, and plays essential roles in defense (30). Moreover, skin is one of the primary locations for drug metabolism, in addition to the liver (29). The 'cocktail' probe substrates approach method has the advantages of high throughput, rapidity and simplicity, and it can reduce the influence of individual differences on the experimental results (31). This method has become an effective part of early high-throughput drug screening and research into mechanisms underlying drug interactions, and is also the main method of drug metabolism research (32). The present study used fenacetin, chlorzoxazol and testosterone as special probe drugs to investigate the activities of CYP1A2, CYP2E1 and CYP3A4, respectively (33). The present results indicated that TP + FA had no significant effect on the activities of CYP1A2, CYP2E1 or CYP3A4 in $\mathrm{HaCaT}$ cells. CYP3A4 is predominant in the metabolism of triptolide, while glycyrrhizin can significantly accelerate the metabolic elimination of TP from the body, mainly via induction of hepatic CYP3A activity and attenuation of the toxicity of TP $(34,35)$; this is inconsistent with the present results. However, this discrepancy could arise for the fact that the content of CYP enzymes in epidermal cells is lower compared with liver cells, thus the results of the interaction between TP and CYP enzymes in epidermal cells were not significant. It is also possible that $\mathrm{HaCaT}$ cells were derived from human abdominal skin in the present study. However, most CYP450 enzymes have interspecies differences in the process of drug biotransformation, and in the affinity between active or toxic drug components (36-38). Therefore, these differences may help to explain why TP + FA did not exert significant effects on the three tested CYP450 enzymes in the present study.

ROS are a metabolic signals produced under normal physiological conditions, and play essential roles in maintaining normal oxidative stress (39). The normal state of redox equilibrium is compromised when ROS levels exceed the capacity of the antioxidant defense system (40), which in turn interrupts cellular activities and induces apoptosis, tissue damage and aging $(41,42)$. Moreover, GSH, MDA, SOD and CAT are important for maintaining redox equilibrium, which is closely implicated in the occurrence and treatment of many diseases $(43,44)$. The present results suggested that TP significantly reduced the survival rate of cells, increased production levels of ROS, MDA and SOD, and decreased GSH and CAT activities in HaCaT cells. These results are in line with previous studies investigating the activation of related genes and disruption of mitochondrial membrane potential, which compromises redox homeostasis, causes oxidative damage and promotes apoptosis in $\mathrm{HaCaT}$ cells (45). The present results indicated that FA reversed the regulatory changes of TP-induced antioxidant factors and protected $\mathrm{HaCaT}$ cells. Our previous study, performed on 

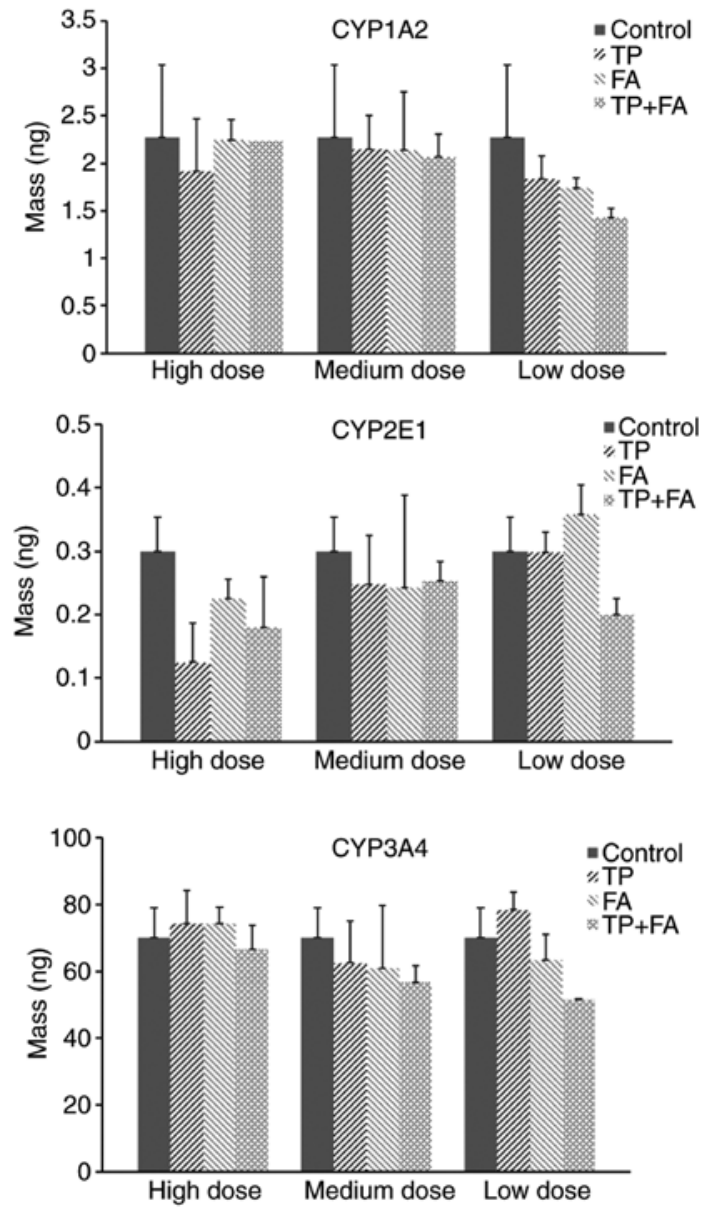

Figure 5. Effect of TP + FA on activities of CYP1A2, CYP2E1 and CYP3A4. TP high dose, $156.25 \mathrm{ng} / \mathrm{ml}$, TP medium dose, $78.13 \mathrm{ng} / \mathrm{ml}$ and TP low dose, $39.07 \mathrm{ng} / \mathrm{ml}$. TP + FA low dose, TP $39.07 \mathrm{ng} / \mathrm{ml}+$ FA $3.907 \mu \mathrm{g} / \mathrm{ml}$, $\mathrm{TP}+\mathrm{FA}$ medium dose, TP $78.13 \mathrm{ng} / \mathrm{ml}+\mathrm{FA} 7.813 \mu \mathrm{g} / \mathrm{ml}$, and TP + FA high dose, TP $156.25 \mathrm{ng} / \mathrm{ml}+\mathrm{FA} 15.625 \mu \mathrm{g} / \mathrm{ml}$. TP, triptolide; FA, ferulic acid; CYP1A2, cytochrome P450 family 1 subfamily A member 2; CYP2E1, cytochrome P450 family 2 subfamily E member 1; CYP3A4, cytochrome P450 family 3 subfamily A member 4 .

Madin-Daby Canine Kidney (MDCK) cells, showed that the toxicity of TP can also be reduced by combining it with FA, which increases the survival probability of MDCK cells (46). Moreover, isoliquiritigenin and glycyrrhetinic are antagonistic to TP-induced damage in HepG2 cells, which may be partly associated with their protective effects in TP-induced oxidative stress (47).

As Nrf2 is a master regulator of detoxification and antioxidative responses, under healthy conditions its expression is tightly regulated and controlled at the protein level $(48,49)$. Furthermore, Nrf2 participates in the synthesis of the antioxidative enzymes GSH, SOD and CAT, by interacting with antioxidant-reaction elements and inducing the expression of downstream targets (50-52). The present study found that the expression of Nrf2 protein was not significantly affected by TP compared with the control group. However, the protein expression of Nrf2 was increased in the TP + FA group, and there was a significant difference in the high-dose group. Therefore, the present results indicated that FA may increase the protein expression of $\mathrm{Nrf} 2$ in $\mathrm{HaCaT}$ cells. However, it cannot be confirmed that the expression of this
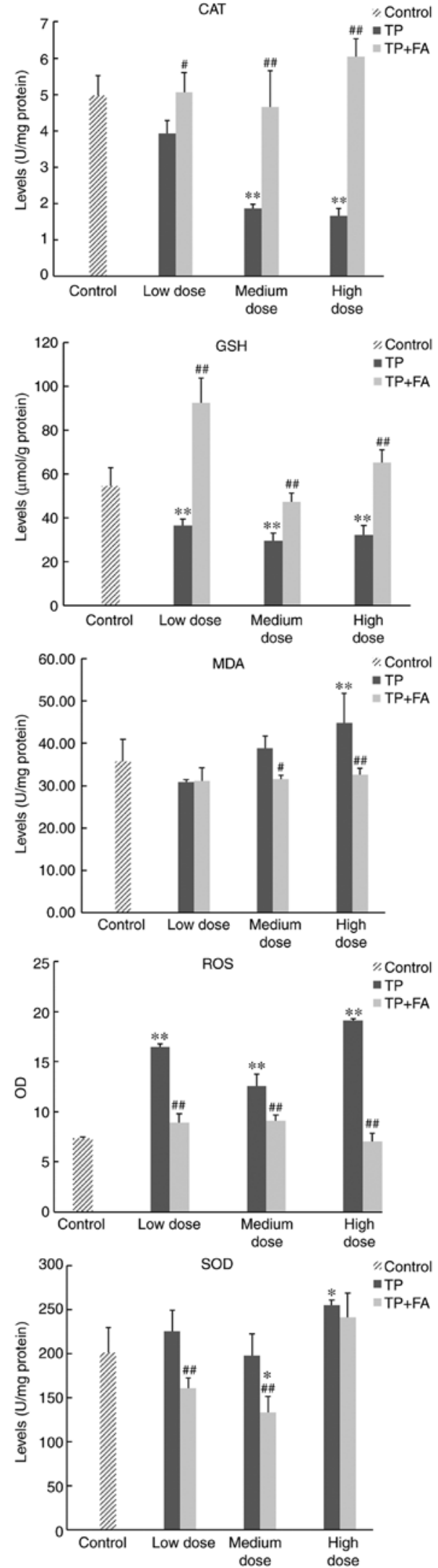

Figure 6. Production levels of ROS, GSH, CAT, SOD and MDA in HaCaT cells. Doses for each group were as follows: Control, without TP or FA; TP low dose, $39.07 \mathrm{ng} / \mathrm{ml}$; TP medium dose, $78.13 \mathrm{ng} / \mathrm{ml}$; TP high dose, $156.25 \mathrm{ng} / \mathrm{ml}$; FA low dose, $3.907 \mu \mathrm{g} / \mathrm{ml}$; FA medium dose, $7.813 \mu \mathrm{g} / \mathrm{ml}$; FA high dose, $15.625 \mu \mathrm{g} / \mathrm{ml}$; $\mathrm{TP}+\mathrm{FA}$ low dose, TP $39.07 \mathrm{ng} / \mathrm{ml}+\mathrm{FA} 3.907 \mu \mathrm{g} / \mathrm{ml} ; \mathrm{TP}+\mathrm{FA}$ medium dose, $\mathrm{TP}$ $78.13 \mathrm{ng} / \mathrm{ml}+\mathrm{FA} 7.813 \mu \mathrm{g} / \mathrm{ml}$; and TP + FA high dose, TP $156.25 \mathrm{ng} / \mathrm{ml}+\mathrm{FA}$ $15.625 \mu \mathrm{g} / \mathrm{ml}$. ${ }^{*} \mathrm{P}<0.05,{ }^{* *} \mathrm{P}<0.01$ vs. control group; ${ }^{\#} \mathrm{P}<0.05,{ }^{\# \#} \mathrm{P}<0.01$ vs. TP group. ROS, reactive oxygen species; GSH, glutathione; CAT, catalase; SOD, superoxide dismutase; MDA, malondialdehyde; TP, triptolide; FA, ferulic acid. 
Table VI. Expression of antioxidant factors in HaCaT cells.

\begin{tabular}{lccccc}
\hline Group & ROS, OD & GSH, $\mu$ mol/g protein & SOD, U/mg protein & CAT, U/mg protein & MDA, nmol/g protein \\
\hline Control & $7.36 \pm 0.11$ & $56.46 \pm 8.52$ & $201.33 \pm 23.83$ & $4.98 \pm 0.54$ & $35.72 \pm 5.23$ \\
TP-low dose & $16.43 \pm 0.35^{\mathrm{b}}$ & $36.36 \pm 2.93^{\mathrm{b}}$ & $225.16 \pm 24.25$ & $3.93 \pm 0.36$ & $30.75 \pm 0.73$ \\
TP-medium dose & $12.59 \pm 1.18^{\mathrm{b}}$ & $29.56 \pm 3.47^{\mathrm{b}}$ & $197.95 \pm 24.50$ & $1.87 \pm 0.11^{\mathrm{b}}$ & $38.82 \pm 2.79$ \\
TP-high dose & $19.09 \pm 0.21^{\mathrm{b}}$ & $31.98 \pm 4.58^{\mathrm{b}}$ & $255.06 \pm 5.46^{\mathrm{a}}$ & $1.66 \pm 0.20^{\mathrm{b}}$ & $44.75 \pm 6.98^{\mathrm{b}}$ \\
FA-low dose & $13.17 \pm 1.77^{\mathrm{b}}$ & $66.42 \pm 9.29$ & $218.47 \pm 21.19$ & $4.83 \pm 0.59$ & $31.33 \pm 4.63$ \\
FA-medium dose & $10.33 \pm 1.22^{\mathrm{b}}$ & $74.67 \pm 4.26^{\mathrm{b}}$ & $168.94 \pm 24.79$ & $4.15 \pm 0.39$ & $30.65 \pm 3.09$ \\
FA-high dose & $8.70 \pm 0.38$ & $65.15 \pm 4.81$ & $149.37 \pm 19.28^{\mathrm{a}}$ & $5.06 \pm 0.60$ & $32.55 \pm 4.40$ \\
TP+FA-low dose & $8.92 \pm 0.88^{\mathrm{d}}$ & $92.33 \pm 11.42^{\mathrm{b}, \mathrm{d}}$ & $160.85 \pm 11.80^{\mathrm{d}}$ & $5.07 \pm 0.53^{\mathrm{d}}$ & $31.10 \pm 3.16$ \\
TP+FA-medium dose & $9.09 \pm 0.60^{\mathrm{d}}$ & $47.11 \pm 4.08^{\mathrm{d}}$ & $133.28 \pm 18.00^{\mathrm{b}, \mathrm{d}}$ & $4.66 \pm 1.00^{\mathrm{d}}$ & $31.54 \pm 0.92^{\mathrm{c}}$ \\
TP+FA-high dose & $7.01 \pm 0.87^{\mathrm{d}}$ & $65.32 \pm 5.68^{\mathrm{d}}$ & $241.33 \pm 27.56$ & $6.05 \pm 0.49^{\mathrm{d}}$ & $32.57 \pm 1.49^{\mathrm{d}}$ \\
\hline
\end{tabular}

Data are presented as the mean \pm SD. Control, without TP and FA; TP-low dose, $39.07 \mathrm{ng} / \mathrm{ml}$; TP-medium dose, $78.13 \mathrm{ng} / \mathrm{ml}$; TP-high dose $156.25 \mathrm{ng} / \mathrm{ml}$; FA-low dose, $3.907 \mu \mathrm{g} / \mathrm{ml}$; FA-medium dose, $7.813 \mu \mathrm{g} / \mathrm{ml}$; FA-high dose, $15.625 \mu \mathrm{g} / \mathrm{ml}$; TP + FA-low dose, TP $39.07 \mathrm{ng} / \mathrm{ml}+$ FA $3.907 \mu \mathrm{g} / \mathrm{ml}$; TP + FA-medium dose, TP $78.13 \mathrm{ng} / \mathrm{ml}+$ FA $7.813 \mu \mathrm{g} / \mathrm{ml}$; and TP + FA-high dose, TP $156.25 \mathrm{ng} / \mathrm{ml}+$ FA $15.625 \mu \mathrm{g} / \mathrm{ml} .{ }^{\mathrm{a}} \mathrm{P}<0.05$, ${ }^{\mathrm{b}} \mathrm{P}<0.01$ vs. control group. ${ }^{\mathrm{C}} \mathrm{P}<0.05,{ }^{\mathrm{d}} \mathrm{P}<0.01$ vs. the corresponding TP group. CAT, catalase; GSH, glutathione; MDA, malondialdehyde; TP, triptolide; FA, ferulic acid; ROS, reactive oxygen species; SOD, superoxide dismutase.

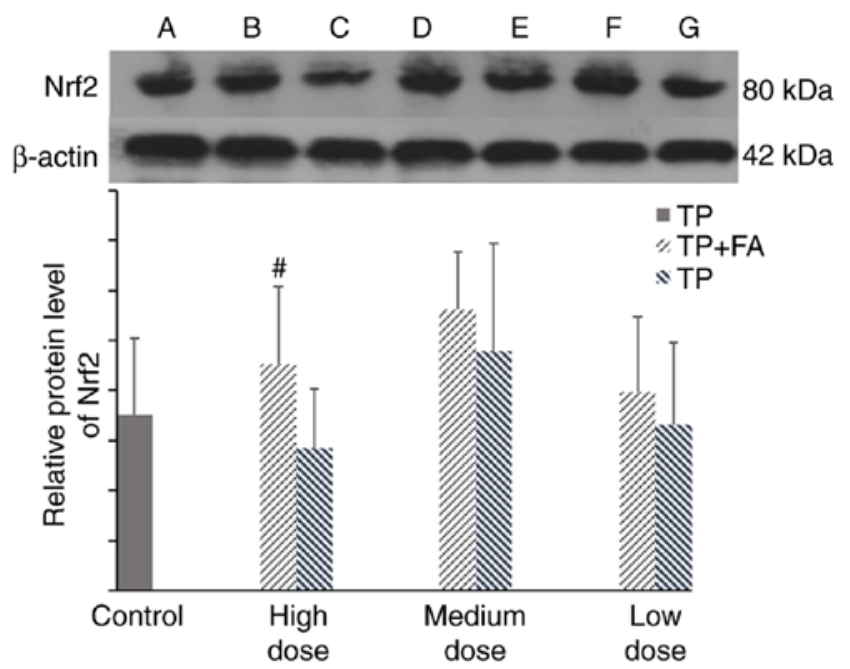

Figure 7. Protein expression of $\mathrm{Nrf} 2$ in $\mathrm{HaCaT}$ cells. Doses for each group were as follows: Control, without TP or FA; TP low dose, $39.07 \mathrm{ng} / \mathrm{ml}$; TP medium dose, $78.13 \mathrm{ng} / \mathrm{ml}$; TP high dose, $156.25 \mathrm{ng} / \mathrm{ml}$; TP + FA low dose, TP $39.07 \mathrm{ng} / \mathrm{ml}+\mathrm{FA} 3.907 \mu \mathrm{g} / \mathrm{ml}$; TP + FA medium dose, TP $78.13 \mathrm{ng} / \mathrm{ml}+\mathrm{FA}$ $7.813 \mu \mathrm{g} / \mathrm{ml}$; and TP + FA high dose, TP $156.25 \mathrm{ng} / \mathrm{ml}+$ FA $15.625 \mu \mathrm{g} / \mathrm{ml}$. A band, control. B, D and F bands are high-, middle- and low-dose TP + FA combination groups, respectively. C, E and $\mathrm{G}$ bands are high-, medium- and low-dose TP-alone groups, respectively. ${ }^{\#} \mathrm{P}<0.05$ vs. TP group. TP, triptolide; FA, ferulic acid; Nrf2, nuclear factor erythroid-2-related factor 2.

downstream antioxidant factor is affected by Nrf2 nuclear transposition (53).

In conclusion, the present results suggested that TP induced injury in $\mathrm{HaCaT}$ cells, whereas TP + FA alleviated this cytotoxicity. However, it was found that TP + FA had no significant effect on the activities of CYP1A2, CYP2E1 and CYP3A4 enzymes in HaCaT cells. Moreover, the underlying mechanisms may be related to the decrease in production of ROS in $\mathrm{HaCaT}$ cells, which increased the production levels of key antioxidant factors and the antioxidative ability of cells, and was associated with a protective effect against oxidative damage.

\section{Acknowledgements}

Not applicable.

\section{Funding}

This work was financially supported by the National Natural Science Foundation (grant no. 81460607), Jiangxi Natural Science Foundation (grant no. 20202BAB206081) and Jiangxi University of Traditional Chinese Medicine 1050 Youth Talent Project (grant. no. 1142001007).

\section{Availability of data and materials}

All data generated or analyzed during this study are included in this published article.

\section{Authors' contributions}

JZ, YG and LC were responsible for the conception and design of the study, acquisition, analysis and interpretation of the data, the drafting and writing of the manuscript, and revisions to its intellectual content. LH and LT were involved in the conception of the study, acquisition, analysis and interpretation of the data, and the drafting of the manuscript. WZ, ZZ and CJ contributed to acquisition and analysis of the data, and the drafting and revision of the manuscript. LC was responsible for the conception and design of the experiments, analysis and interpretation of the data, the drafting of the manuscript, and revisions to its intellectual content. All authors have read and approved the final manuscript.

\section{Ethics approval and consent to participate}

Not applicable.

\section{Patient consent for publication}

Not applicable. 


\section{Competing interests}

The authors declare that they have no competing interests.

\section{References}

1. Tu L, Su P, Zhang Z, Gao L, Wang J, Hu T, Zhou J, Zhang Y, Zhao Y, Liu Y, et al: Genome of tripterygium wilfordii and identification of cytochrome $\mathrm{P} 450$ involved in triptolide biosynthesis. Nat Commun 11: 971, 2020.

2. Cai A, Qi S, Su Z, Shen H, Ma W and Dai Y: Tripterygium glycosides inhibit inflammatory mediators in the rat synovial RSC-364 cell line stimulated with interleukin-1 3 . Biomed Rep 3: 763-766, 2015.

3. Cui J, Chen X and Su J: Advanced progress of main pharmacology activities of triptolide. Zhongguo Zhong Yao Za Zhi 42 2655-2658, 2017 (In Chinese).

4. Wang J, Chu Y and Zhou X: Inhibitory effect of triperygium wilfordii polyglucoside on dipeptidyl peptidase I in vivo and in vitro. Biomed Pharmacother 96: 466-470, 2017.

5. Fan D, Guo Q, Shen J, Zheng K, Lu C, Zhang G, Lu A and He X: The effect of triptolide in rheumatoid arthritis: From basic research towards clinical translation. Int J Mol Sci 19: 376, 2018

6. Gu Y, Yang M, Tang X, Wang T, Yang D, Zhai G and Liu J: Lipid nanoparticles loading triptolide for transdermal delivery: Mechanisms of penetration enhancement and transport properties. J Nanobiotechnology 16: 68, 2018.

7. Shan Q, Jiang X, Wang F, Shu Z and Gui S: Cubic and hexagonal liquid crystals as drug carriers for the transdermal delivery of triptolide. Drug Deliv 26: 490-498, 2019.

8. Zhang L, Chang J, Zhao Y, Xu H, Wang T, Li Q, Xing L, Huang J, Wang Y and Liang Q: Fabrication of a triptolide-loaded and poly- $\gamma$-glutamic acid-based amphiphilic nanoparticle for the treatment of rheumatoid arthritis. Int J Nanomedicine 13 . 2051-2064, 2018

9. Zhao Y, Guan Y, Le X, Zhu W and Chen L: Experimental research on acute toxicity and skin irritation of triptolide microemulsion gel. Shanghai Chin Med J 44: 75-77, 2010.

10. Mathew S and Abraham TE: Bioconversions of ferulic acid, an hydroxycinnamic acid. Crit Rev Microbiol 32: 115-125, 2006.

11. Ganesan R and Rasool M: Ferulic acid inhibits interleukin 17-dependent expression of nodal pathogenic mediators in fibroblast-like synoviocytes of rheumatoid arthritis. J Cell Biochem: Aug 30, 2018 (Epub ahead of print). doi: 10.1002/jcb.27502.2018.

12. Sgarbossa A, Giacomazza D and Di Carlo M: Ferulic acid: A hope for Alzheimer's disease therapy from plants. Nutrients 7 : 5764-5782,2015

13. Tao L, Xiao F, Zhu W, Chen L, Guan Y, Jin C and Wu L: Attenuation effect of tripterygii Radix et Rhizoma. Chin J Exp Trad Med For 23: 230-234, 2017 (In Chinese).

14. Tao L, Guan Y, Chen L, Xiao F, Jin C and Zang Z: Research progress on detoxicity by tripterygii Radix et Rhizoma compatibility. Chin J Exp Trad Med For 24: 229, 2018 (In Chinese).

15. Guan Y, Tao L, Xiao F, Chen L, Zhu Y, Jin C and Zang Z: Prescription rules of preparations containing tripterygium wilfordii Hook.f.against rheumatoid arthritis. Chin J Hosp Pharm 38: 64-68, 2018 (In Chinese).

16. Park JH, Lee JE, Choi SS and Park TH: Protective effects of silkworm hemolymph extract and its fractions on UV-induced photoaging. Biotechnol Bioprocess Engineering 22: 37-44, 2017.

17. Farrar MD, Nicolaou A, Clarke KA, Mason S, Massey KA, Dew TP, Watson RE, Williamson G and Rhodes LE: A randomized controlled trial of green tea catechins in protection against ultraviolet radiation-induced cutaneous inflammation. Am J Clin Nutr 102: 608-615, 2015

18. Narasaiah UL: Antioxidants and Human Diseases. In: Clinica Chimica Acta. PubMed, p16, 2014

19. Swanson HI: Cytochrome P450 expression in human keratinocytes: An aryl hydrocarbon receptor perspective. Chem Biol Interact 149: 69-79, 2004

20. Smith G, Wolf CR, Deeni YY, Dawe RS, Evans AT, Comrie MM, Ferguson J and Ibbotson SH: Cutaneous expression of cytochrome P450 CYP2S1: Individuality in regulation by therapeutic agents for psoriasis and other skin diseases. Lancet 361: 1336-1343, 2003

21. Chopra D, Ray L, Dwivedi A, Tiwari SK, Singh J, Singh KP, KushwahaHN,Jahan S,Pandey A, Gupta SK, et al:Photoprotective efficiency of PLGA-curcumin nanoparticles versus curcumin through the involvement of ERK/AKT pathway under ambient UV-R exposure in HaCaT cell line. Biomaterials 84: 25-41, 2016
22. Fabian E, Vogel D, Blatz V, Ramirez T, Kolle S, Eltze T, van Ravenzwaay B, Oesch F and Landsiedel R: Xenobiotic metabolizing enzyme activities in cells used for testing skin sensitization in vitro. Arch Toxicol 87: 1683-1696, 2013.

23. Bi YF, Zheng Z, Pi ZF, Liu ZQ and Song FR: The metabolic fingerprint of the compatibility of Radix Aconite and Radix Paeoniae Alba and its effect on CYP450 enzymes. Yao Xue Xue Bao 49: 1705-1710, 2014 (In Chinese).

24. Liao HW, Chen GY, Wu MS, Liao WC, Tsai IL and Kuo CH: Quantification of endogenous metabolites by the postcolumn infused-internal standard method combined with matrix normalization factor in liquid chromatography-electrospray ionization tandem mass spectrometry. J Chromatogr A 1375: 62-68, 2015.

25. Liu JQ, Li Q, Zhang R, Liu F, Zhang W, He ZH, Hong Q, Kou XL and $\mathrm{Wu} \mathrm{JM}$ : LC-MS/MS studies on effect of Glycyrrhiza uralensis on metabolism, distribution and excretion of triptolide in rat. Chin J Pharm Anal 30: 1664-1671, 2010.

26. Huang QX, Lei HH, Tang HR and Wang YL: Quantitative analysis of ceramides by ultrahigh-performance liquid chromatography tandem mass spectrometry. Journal of Shanghai Jiao Tong University 39: 1353-1359, 2019.

27. Eagling VA, Tjia JF and Back DJ: Differential selectivity of cytochrome $\mathrm{P} 450$ inhibitors against probe substrates in human and rat liver microsomes. Br J Clin Pharmacol 45: 107-114, 1998

28. Liu A, Qi X, Zhang YC, Xu TX, Yi J and Yang J: Principle and applications of fluorescent probes for intracellular redox detection. J Shanghai Jiao Tong University (Medical Edition) 38: 101-107, 2018.

29. Chen XF: Current and future technological advances in transdermal gene delivery. Adv Drug Deliv Rev 127: 85-105, 2018

30. Cui L, Jia Y, Cheng Z, Gao Y, Zhang G, Li J and He C: Advancements in the maintenance of skin barrier/skin lipid composition and the involvement of metabolic enzymes. J Cosmet Dermatol 15: 549-558, 2016.

31. Hou CS, Yang ZH and Sun XB: Progress of 'cocktail' probe substrates approach and its application in studies of traditional Chinese materia medica on cytochrome P450 system. Chin J Pharmacol Toxicol 27: 445-450, 2013

32. De Andrés F, Terán S, Bovera M, Fariñas H, Terán E and LLerena A: Multiplex phenotyping for systems medicine: A one-point optimized practical sampling strategy for simultaneous estimation of CYP1A2, CYP2C9, CYP2C19, and CYP2D6 activities using a cocktail approach. Omics 20: 88-96, 2016.

33. Bi Y, Zheng Z, Pi Z, Liu Z and Song F: The metabolic fingerprint of the compatibility of radix aconite and radix paeoniae alba and its effect on CYP450 enzymes. Yao Xue Xue Bao 49: 1705-1710, 2014 (In Chinese).

34. Tai T, Huang X, Su Y, Ji J, Su Y, Jiang Z and Zhang L: Glycyrrhizin accelerates the metabolism of triptolide through induction of CYP3A in rats. J Ethnopharmacol 152: 358-363, 2014

35. Xu Y, Zhang YF, Chen XY and Zhong DF: CYP3A4 inducer and inhibitor strongly affect the pharmacokinetics of triptolide and its derivative in rats. Acta Pharmacol Sin 39: 1386-1392, 2018.

36. Martignoni M, Groothuis GM and de Kanter R: Species differences between mouse, rat, dog, monkey and human CYP-mediated drug metabolism, inhibition and induction. Expert Opin Drug Metab Toxicol 2: 875-894, 2006.

37. Uno Y,Hosaka S,Matsuno K, Nakamura C,Kito G, Kamataki T and Nagata R: Characterization of cynomolgus monkey cytochrome P450 (CYP) cDNAs: Is CYP2C76 the only monkey-specific CYP gene responsible for species differences in drug metabolism? Arch Biochem Biophys 466: 98-105, 2007.

38. Heikkinen AT, Friedlein A, Matondo M, Hatley OJ, Petsalo A, Juvonen R, Galetin A, Rostami-Hodjegan A, Aebersold R, Lamerz J, et al: Quantitative ADME Proteomics-CYP and UGT enzymes in the beagle dog liver and intestine. Pharm Res 32: 74-90, 2015.

39. Fujii $\mathrm{H}$, Emoto $\mathrm{M}$ and Sato-Akaba $\mathrm{H}$ : Brain redox imaging using in vivo electron paramagnetic resonance imaging and nitroxide imaging probes. Magnetochemistry 5: 11, 2019.

40. Volpe CM, Villar-Delfino PH, dos Anjos PM and Nogueira-Machado JA: Cellular death, reactive oxygen species (ROS) and diabetic complications. Cell Death Dis 9: 119, 2018.

41. Labuschagne CF and Brenkman AB: Current methods in quantifying ROS and oxidative damage in caenorhabditis elegans and other model organism of aging. Ageing Res Rev 12: 918-930, 2013.

42. Poljsak B, Šuput D and Milisav I: Achieving the balance between ROS and antioxidants: When to use the synthetic antioxidants. Oxid Med Cell Longev 2013: 956792, 2013. 
43. Slatter DA, Bolton $\mathrm{CH}$ and Bailey AJ: The importance of lipid-derived malondialdehyde in diabetes mellitus. Diabetologia 43: 550-557, 2000.

44. Cacciatore I, Baldassarre L, Fornasari E, Mollica A and Pinnen F Recent advances in the treatment of neurodegenerative diseases based on GSH delivery systems. Oxid Med Cell Longev 2012: 240146, 2012.

45. Shen SC, Lee WR, Yang LY, Tsai HH, Yang LL and Chen YC: Quercetin enhancement of arsenic-induced apoptosis via stimulating ROS-dependent $\mathrm{p} 53$ protein ubiquitination in human HaCaT keratinocytes. Exp Dermatol 21: 370-375, 2012.

46. He L, Tao L, Guan Y, Chen L, Zhu W, Jin C and Wu L: Preparation and evaluation of triptolide and ferulic acid ethosomes. Chin Tradit Herbal Drugs 49: 2817-2825, 2018.

47. Cao L, Li H, Yan M, Li Z, Gong H, Jiang P, Deng Y, Fang P and Zhang B: The protective effects of isoliquiritigenin and glycyrrhetinic acid against triptolide-induced oxidative stress in HepG2 cells involve Nrf2 activation. Evid Based Complement Alternat Med 2016: 8912184, 2016.

48. Vomund S, Schäfer A, Parnham M, Brüne B and von Knethen A: $\mathrm{Nrf} 2$, the master regulator of anti-oxidative responses. Int $\mathbf{J} \mathrm{Mol}$ Sci 18: 2772, 2017

49. Ishii T and Warabi E: Mechanism of rapid nuclear factor-E2-related factor 2 (Nrf2) activation via membrane-associated estrogen receptors: Roles of NADPH oxidase 1, neutral sphingomyelinase 2 and epidermal growth factor receptor (EGFR). Antioxidants (Basel) 8: 69, 2019.
50. Oyake $\mathrm{T}$, Itoh $\mathrm{K}$, Motohashi $\mathrm{H}$, Hayashi $\mathrm{N}$, Hoshino $\mathrm{H}$, Nishizawa $M$, Yamamoto $M$ and Igarashi $K$ : Bach proteins belong to a novel family of BTB-basic leucine zipper transcription factors that interact with MafK and regulate transcription through the NF-E2 site. Mol Cell Biol 16: 6083-6095, 1996.

51. Gan L and Johnson JA: Oxidative damage and the Nrf2-ARE pathway in neurodegenerative diseases. Biochim Biophys Acta 1842: 1208-1218, 2014.

52. Tang W, Jiang YF, Ponnusamy M and Diallo M: Role of Nrf2 in chronic liver disease. World J Gastroenterol 20: 13079-13087, 2014.

53. Wang Y, Guo SH, Shang XJ, Yu LS, Zhu JW, Zhao A, Zhou YF, An GH, Zhang Q and Ma B: Triptolide induces Sertoli cell apoptosis in mice via ROS/JNK-dependent activation of the mitochondrial pathway and inhibition of Nrf2-mediated antioxidant response. Acta Pharmacol Sin 39: 311-327, 2018.

This work is licensed under a Creative Commons Attribution-NonCommercial-NoDerivatives 4.0 International (CC BY-NC-ND 4.0) License. 